M. Bylsma-Howell MD, K, W. Riggs B SC MSC, G.H. McMorland MB CH B RCPS FRCP(C), D. W. Rurak PHD, R. Ongley MD FRCP(C), B. McErlane BSC RT, J.D.E. Price MD FRCP(C) FACP, J.E. Axelson PHD

\title{
Placental transport of metoclopramide: Assessment of maternal and neonatal effects
}

Twenty-three patients undergoing general anaesthesia for Caesarian section for healthy term pregnancies were entered into a double blind siudy using metoclopramide (MCP) and a normal saline placebo. Of these patients, eight received intravenous metoclopramide, 12 a normal saline placebo and three were iost to cliniral follow-up. The maternal gastric volumes were measured and maternat and foetal MCP plasma concentrations were determined by gas-liquid chromatography. The Neurological and Adaptive Capacity Score tests of Amiel, Barrier and Schnider (NACS) were used to attempt evaluation of neonatal responses to MCP. Maternal gastric volume was significantly lower $(p<0.05)$ in the treated patients. There were no marked differences in Apgar scores, cardiovascular paramelers or neurobehavioural scores between the treated and untreated groups of neonates. At no time were the foetal metoclopramide plasma concentrations observed to exceed maternal values.

Key words

PREMEDICATION: metoclopramide, placental transport, foetal effects.

From the Faculty of Pharmaceutical Sciences and Medicine, University of British Columbia, Vancouver, B.C.

Address correspondence to: Dr. J.E. Axelson, 2146 East Mall, University of British Columbia, Vancouver, B.C. V6T 1W5.
Aspiration of stomach contents during obstetrical anaesthesia is still the most common cause of maternal mortality due to anaesthesia; it is the fourth overall cause of matemal death after haemorthage, toxaemia and sepsis. ${ }^{l}$ Ever since Mendel$\operatorname{son}^{2}$ in 1946 first described the syndrome of pulmonary aspiration in obstetric patients undergoing general anaesthesia, there have been studies to elucidate mechanisms involved. Gastric volume and $\mathrm{pH}$ are important contributing factors and it is generally well accepted that gastric contents with a volume of less than $0.4 \mathrm{ml} \cdot \mathrm{kg}^{-1}$ and a hydrogen ion concentration $\left[\mathrm{H}^{+}\right]$of less than $3.16 \times 10^{-3}$ milliequivalents per litre $\left(\mathrm{mEq} \cdot \mathrm{I}^{-1}\right)$ are probably not hazardous.

Some of the commonly employed preventative measures aimed at reducing the incidence of pulmonary aspiration consist of fasting patients during labour and prior to elective Caesarian section, rapid sequence induction with cricoid pressure and the use of antacids.

Foulkes and Jenkins ${ }^{3}$ have shown that both the oral non-particulate antacid, sodium citrate $(0.3 \mathrm{M})$ and the histamine $\mathrm{H}_{2}$-receptor antagonist, cimetidine, effectively raise the $\mathrm{pH}$ above 2.5 , the deemed critical value. ${ }^{4}$ It should be considered, however, that the administration of $30 \mathrm{ml}$ of sodium citrate may raise the gastric volume appreciably, further contributing to the risk of gastric aspiration. The use of antacid therapy to raise maternal gastric $\mathrm{pH}$ is also not considered to be invariably reliable. ${ }^{5}$

A more recent method of reducing aspiration risk involves the use of the potent antiemetic and gastric motility modifier metoclopramide (MCP). Metoclopramide has been shown to significantly diminish the frequency of vomiting during labour, ${ }^{6}$ as well as to increase the gastric emptying rate ${ }^{7}$ and 
tone of the lower oesophageal sphincter, ${ }^{8}$ both of which are reduced in labour. These positive actions of MCP have led to its more frequent use in obstetrical anaesthesia in Canada as well as in Europe and Japan. ${ }^{9}$

In view of MCP's potential to reduce maternal mortality due to pulmonary aspiration it is used increasingly in parturient women undergoing general anaesthesia. Unfortunately, little is known of the potential for MCP placental transport and its possible effects upon the neonate. ${ }^{6,7}$ It is recognized, however, that there are reports of an increased incidence of side effects (agitation, irritability, extra-pyramidal dystonia) with MCP in infants and young children, although in most cases the recommended dose of MCP had been exceeded. ${ }^{10,11}$

The present report describes the results of a placental transport study conducted in a doubleblind fashion in parturient women undergoing elective Caesarian section. Maternal and foetal plasma concentrations of MCP have been measured using an electron-capture gas-liquid chromatography assay method recently developed in our laboratory for use in placental transport studies in humans and sheep. ${ }^{12}$ Maternal drug effects of MCP have been assessed through measurement of gastric volumes and neonatal drug effects determined using Apgar and the NACS neurobehavioural tests. ${ }^{13}$

\section{Materials and methods}

This study received the approval of the Ethics Committee on Human Experimentation which decided specific consent was not required. Patient selection was limited to ASA (American Society of Anaesthesiologists) Physical Status Class I individuals who wished to have general anaesthesia for delivery of full-term gestation where there was no evidence of foetal distress. All patients were comparable as regards to age, weight and gestational age, while none of the patients experienced dyspeptic symptoms other than the oesophageal refluxing commonly encountered in late pregnancy. Twentythree patients were fasted overnight and were given $30 \mathrm{ml} 0.3 \mathrm{M}$ sodium citrate p.o., one hour prior to induction of anaesthesia. Metoclopramide $(\overline{\mathrm{x}}=$ $0.14 \pm 0.02 \mathrm{mg} \cdot \mathrm{kg}^{-1}$ ) or an equivalent volume of placebo normal saline was administered intravenously in a randomized couble blind manner approximately 30 minutes preoperatively $(\bar{x}=$ $30.60 \pm 10.34 \mathrm{~min}$; range, $12-51 \mathrm{~min}$.).

Anaesthesia was induced in all patients using standard techniques of rapid sequence induction and cricoid pressure. Thiopental $4.0 \mathrm{mg} \cdot \mathrm{kg}^{-1}$ ( \pm $1.4 \mathrm{mg}$ ) was used for induction. All patients were subsequently maintained with $\mathrm{N}_{2} \mathrm{O}: \mathrm{O}_{2}:: 50: 50$ and halothane 0.5 per cent prior to delivery of the infant. Following delivery a Salem gastric tube (14 gauge) was inserted orally by an independent observer and maternal stomach contents were aspirated until dry. These results were recorded and filed in a sealed envelope until completion of the study. A maternal venous (MV) blood sample was taken after induction of anaesthesia prior to the delivery of the infant. Both umbilical venous (UV) and arterial (UA) blood samples were obtained at delivery from a doubly clamped section of the umbilical cord. The samples were then placed in heparinized tubes, centrifuged and the plasma removed and frozen $\left(-20^{\circ} \mathrm{C}\right)$ for later analysis using an assay method recently established in our laboratory capable of metoclopramide measurement with an average coefficient of variation of 5-6 per cent. ${ }^{12}$

Apgar scores were assessed by the attending paediatric intensive care nursery team at one and five minutes. Neonatal heart rate and blood pressure (systolic) (by Arteriosonde*) were recorded one hour after birth. One examiner, blind to the gastric volume aspiration data, scored and evaluated the infants at two, four, six and 24 hours of age using the NACS Neurcbehavioural test. This examiner was a resident in anaesthesia with special training in neonatal care.

Analysis of the accumulated data on each of the following parameters: gestational age, birth weight, heart rate, blood pressure, maternal gastric volume, maternal age and weight, dose of MCP and administration times was completed using the Students' t-test subprogramme of the Statistical Package for the Sccial Sciences version 9 (SPSS:9). ${ }^{14}$ Significance was determined at the 0.05 level.

\section{Results}

Three infants developed respiratory difficulties at delivery and were subsequently transferred to the intensive care nursery (ICN). Since these babies *Roche Model 1010 Arteriosonde, Ruche Medical Electronics, Cranbury, N.J. 08512 
TABL.E I Plasma analysis data

\begin{tabular}{|c|c|c|c|c|c|c|c|c|c|}
\hline \multirow[b]{2}{*}{$\begin{array}{l}\text { Patient } \\
\text { code }\end{array}$} & \multicolumn{3}{|c|}{ Matemal } & \multicolumn{2}{|c|}{$\begin{array}{l}\text { Sample elapsed time } \\
\text { (min) }\end{array}$} & \multirow{2}{*}{$\begin{array}{l}\text { Maternal } \\
\text { gastric } \\
\text { volume (ml) }\end{array}$} & \multicolumn{3}{|c|}{ Plasma $M C P$ concentrations (ng $\cdot \mathrm{ml}^{-1} \mathrm{~s}^{3}$} \\
\hline & $\begin{array}{l}\text { Age } \\
\text { (yrs) }\end{array}$ & $\begin{array}{l}W t \\
(\mathrm{~kg})\end{array}$ & $\begin{array}{l}\text { I.V. Dose } \\
\left(\mathrm{mg} \cdot \mathrm{kg}^{-1}\right)\end{array}$ & $M V^{\prime}$ & $U M B^{2}$ & & $M V$ & $U V$ & $U A$ \\
\hline \multicolumn{10}{|c|}{$M C P$ irealed } \\
\hline $2 S$ & 28 & 68 & 0.15 & 29 & 32 & 35 & $61.16 \pm 0.22$ & $18.82 \pm 0.13$ & $18.28^{4}$ \\
\hline $5 S$ & 24 & 70 & 0.10 & 34 & 42 & 35 & $57.22 \pm 1.97$ & $38.64 \pm 2.43$ & $38.06^{4}$ \\
\hline 95 & 23 & 80 & 0.15 & 21 & 30 & 8 & $63.01 \pm 3.12$ & $38.75 \pm 3.27$ & $32.78^{4}$ \\
\hline $12 S$ & 27 & 84 & 0.14 & 50 & 53 & 4 & $49.06 \pm 3.51$ & $45.57 \pm 3.64$ & $43.02 \pm 1.05$ \\
\hline 195 & 20 & 68 & 0.15 & 31 & 30 & 9 & $85.03 \pm 2.05$ & $48.57 \pm 0.78$ & $48.14^{4}$ \\
\hline $22 S$ & 23 & 63 & 0.14 & 15 & 19 & 12 & $57.72 \pm 2.02$ & $35.71 \pm 0.53$ & $24.79 \pm 1.10$ \\
\hline $29 \mathrm{~s}$ & 31 & 90 & 0.15 & 32 & 36 & 14 & $42.19 \pm 0.49$ & $25.87 \pm 0.15$ & $30.53 \pm 2.31$ \\
\hline 345 & 33 & 75 & 0.15 & 30 & 34 & 35 & $74.34 \pm 2.50$ & $37.05 \pm 0.62$ & $34.80+1.95$ \\
\hline$\overline{\mathrm{X}}$ & 26.13 & 74.75 & 0.14 & 30.25 & 34.50 & $19.00^{5}$ & 61.22 & 36.12 & 33.80 \\
\hline SD & \pm 4.42 & \pm 9.24 & \pm 0.02 & \pm 10.19 & \pm 9.91 & \pm 13.57 & \pm 13.53 & \pm 9.73 & \pm 9.59 \\
\hline
\end{tabular}

\begin{tabular}{|c|c|c|c|c|c|c|c|c|c|}
\hline \multicolumn{10}{|c|}{ Placabo } \\
\hline 15 & 31 & 60 & 0.15 & 34 & 37 & 165 & - & - & - \\
\hline $3 S$ & 22 & 62 & 0.15 & 51 & 59 & 190 & - & - & - \\
\hline $7 S$ & 29 & 82 & 0.12 & 27 & 35 & 20 & - & - & - \\
\hline $8 S$ & 33 & 64 & 0.14 & 24 & 28 & 63 & - & - & - \\
\hline 105 & 27 & 55 & 0.10 & 12 & 20 & 52 & - & - & - \\
\hline $16 \mathrm{~S}$ & 28 & 75 & 0.15 & 45 & 56 & 48 & - & - & - \\
\hline 269 & 31 & 86 & 0.14 & 28 & 36 & 15 & - & - & - \\
\hline $28 S$ & 30 & 70 & 0.14 & 21 & 22 & 5 & - & - & - \\
\hline $30 S$ & 37 & 90 & 0.15 & 30 & 31 & 27 & - & - & - \\
\hline $32 S$ & 34 & 86 & 0.14 & 25 & 36 & 5 & - & - & - \\
\hline 335 & 30 & 52 & 0.15 & 40 & 46 & 30 & - & - & - \\
\hline $42 S$ & 27 & 53 & 0.14 & 26 & 30 & 95 & - & - & - \\
\hline $\bar{x}$ & 29.92 & 71.25 & 0.14 & 30.25 & 36.33 & 59. & & & \\
\hline $\mathrm{SD}$ & \pm 3.85 & $\$ 12.06$ & \pm 0.02 & \pm 10.77 & \pm 12.09 & \pm 61 . & & & \\
\hline
\end{tabular}

${ }^{3} \mathrm{MCF}$ administration time - MV sample time.

${ }^{2}$ Umbilical samples (UV, UA); MCP adminiștration time - delivery time.

${ }^{3}$ Mear ( $\left.\bar{X}\right)$ of (wo separate determinations $=$ one standard deviation (SD).

${ }^{4}$ Single determination.

sSignificantly different at $\mathrm{p}<0.05$, Students ${ }^{*}$-test (SPSS-9) ${ }^{14}$

were lost to neurological follow-up, viz., Apgar and NACS assessment, they, along with their mothers, were excluded from the study thus reducing the number of participants to 20 .

Eight out of the 20 patients who were involved in the double-blind study received MCP while the remaining 12 were given sodium chloride for injection, as evidenced by the lack of a chromatographic peak for MCP. The results of the plasma determinations were in agreement with the coded treatments when the code was broken following completion of the plasma analyses. Plasma MCP concentrations (MV, UV, UA) are presented in
Table I illustrating that MCP does undergo placental transfer. In no instance did foetal cord plasma MCP concentrations (UV, UA) exceed maternal values over the period of study (12-53 $\mathrm{min}$. following MCP administration).

The results of MCP's effect on maternal gastric volume are also shown in Table I. There is a significant difference (Students' t-test, $p<0.05$ ) between the volumes of treated and untreated patients $(\overline{\mathrm{x}}=19.0 \pm 13.5 \mathrm{ml}$ is $\overline{\mathrm{x}}=59.5 \pm$ $61.0 \mathrm{ml}$ ) confirming the observation of others. ${ }^{7}$ It can also be observed that there is a wide variation in the gastric volumes within the untreated group. 
TABLE II Infant data

\begin{tabular}{|c|c|c|c|c|c|c|}
\hline Patient Code & $\begin{array}{l}\text { Gestational } \\
\text { age } \\
\text { (weeks) }\end{array}$ & $\begin{array}{l}S e x \\
(M, F)\end{array}$ & $\begin{array}{l}\text { Birrh Weight } \\
\text { (g) }\end{array}$ & $\begin{array}{l}\text { Apgar' } \\
\text { Score }\end{array}$ & $\begin{array}{l}H R \\
b p m\end{array}$ & $\begin{array}{l}B P \\
\text { (sysiolic) } \\
\left(m m \cdot H_{g}\right)\end{array}$ \\
\hline \multicolumn{7}{|l|}{ MCP treated } \\
\hline $2 S$ & 40 & $\mathbf{M}$ & 3800 & 8.9 & 148 & 55 \\
\hline $5 S$ & 40 & $\mathbf{M}$ & 3060 & 8,9 & 122 & 65 \\
\hline $9 \mathrm{~S}$ & 40 & $\mathrm{~F}$ & 4060 & 9,10 & 140 & 58 \\
\hline $12 S$ & 39 & $\mathrm{~F}$ & 3540 & 9,9 & 160 & 56 \\
\hline $19 S$ & 39 & $\mathrm{~F}$ & 2690 & 9,9 & 150 & 58 \\
\hline $22 S$ & 40 & M & 3070 & 8,9 & 148 & 56 \\
\hline $29 S$ & 39 & $\mathrm{~F}$ & 3670 & 9.9 & 150 & 50 \\
\hline $34 \$$ & 39 & $F$ & 4760 & 9,10 & 160 & 68 \\
\hline$\overline{\mathrm{X}}$ & 39.5 & & 3581 & & 147 & 58 \\
\hline SD & \pm 0.5 & & \pm 6.55 & & \pm 12 & \pm 8 \\
\hline \multicolumn{7}{|l|}{ Placebo } \\
\hline $1 S$ & 40 & $F$ & 3340 & 9,9 & 150 & 55 \\
\hline 35 & 40 & $F$ & 3900 & $3,9 *$ & 169 & 74 \\
\hline 75 & 38 & $\mathrm{~F}$ & 3910 & 8,9 & 145 & 54 \\
\hline 85 & 38 & F & 3240 & 8,9 & 152 & 68 \\
\hline JoS & 38 & $\mathrm{~F}$ & 2960 & 8,10 & 145 & 62 \\
\hline 165 & 39 & $F$ & 3380 & 8,9 & 160 & 46 \\
\hline $26 S$ & 40 & $M$ & 3050 & 7,9 & 140 & 58 \\
\hline 285 & 40 & $\mathrm{~F}$ & 3220 & 8,9 & 176 & 52 \\
\hline $30 S$ & 40 & $F$ & 3858 & 8,9 & 150 & 58 \\
\hline $32 S$ & 40 & $\mathbf{M}$ & 4680 & 8,9 & 148 & 60 \\
\hline $33 S$ & 38 & $\mathbf{M}$ & 3040 & 8,9 & 160 & 56 \\
\hline $42 S$ & 40 & $\mathbf{M}$ & 2840 & 9,10 & 140 & 50 \\
\hline $\bar{x}$ & 39.3 & & 3451.5 & & 153 & 58 \\
\hline SD & \pm 0.1 & & \pm 154 & & \pm 11 & \pm 8 \\
\hline
\end{tabular}

'Apgar scores determined at one and five minutes post delivery (,).

*Unanticipated problems at delivery likely contributed to low I min Apgar score.

Roberts and Shirley ${ }^{4}$ have also shown that there is a large range in gastric volumes in patients fasted for 8-12 hours prior to delivery by Caesarian section.

Application of the Students' t-test to the analysis of gestational age, sex distribution, birth weight and cardiovascular parameters (HR, BP) demonstrated no significant differences between the treated and untreated groups (Table II). Although the BPs appear low, this may be a measurement artifact associated with the use of the Arteriosonde. All babies were pink and well perfused at birth, with good peripheral pulses.

The results of one and five minute Apgar assessments are presented in Table II. Except for baby $3 \mathrm{~S}$ (in the untreated group) who had a low Apgar score because of unexpected problems at delivery, all of the one minute Apgar scores and all five minute scores were $\geq 7$. These findings are in agreement with previous Apgar score measurements where maternal administration of MCP occurred. ${ }^{7}$

The summarized findings of the NACS tests are presented in Table III. At two, four and six hours a considerable number of the infants in both groups were mildly depressed (NACS scores <33; range, 24-32) while at 24 hours all had scores of 33 or more (range 33-39). The raw scores were subjected to a $2 \times 4$ repeated measures analysis of variance using the ANOVAR subroutine of SPSS: $9^{14}$ which showed no significant differences between the treated and untreated groups. The charts of the infants were also carefully reviewed for records of abnormal movements, restlessness, undue drowsiness or difficulty in reeding; none of the infants in either the test or control group cxperienced any identifiable problems.

One patient (19S) experienced transient dys- 
TABLE III Percentage of neurological and adaptive capacity scores (NACS) less than 33

\begin{tabular}{lllll}
\hline $\begin{array}{l}\text { Infant post-delivery } \\
\text { assessment times (hours) }\end{array}$ & 2 & 4 & 6 & 24 \\
\hline Treated & 50 & 50 & 38 & 0 \\
Placebo & 75 & 42 & 50 & 0 \\
\hline
\end{tabular}

phoric restlessness $10-15 \mathrm{~min}$. following MCP injection; however, this mother's baby showed no marked difference in either Apgar or NACS scores.

\section{Discussion}

Pinder et al. ${ }^{10}$ discussed the toxic reactions encountered with MCP administration in children and infants. Such adverse reactions have included agitation, irritability and the usual manifestations of extrapyramidal dystonia. In view of the increased incidence of side effects encountered in the young, it seemed appropriate to assess MCP placental transport and to perform neurological evaluation of the infant.

Metoclopramide with its low molecular weight and high lipid solubility has been postulated to be transferred across the placenta subsequent to maternal administration; ${ }^{9.15}$ however, there are no reports on this topic in the literature ${ }^{9,15}$ Our study demonstrates that metoclopramide does cross the placenta resulting in measurable concentrations in cord blood (Table I).

In a recent review, Waddell and Marlowe ${ }^{16}$ noted that only a limited interpretation could be made on the basis of such a single-point determination in human studies of placental transport. While these studies do demonstrate drug transfer, comparisons of maternal and foetal (cord) levels must be made cautiously since a distribution equilibrium state between mother and foetus may or may not have been attained at the time of delivery and sampling. Since ethical considerations preclude in utero foetal blood sampling in humans, the present investigators have initiated a comprehensive study of MCP placental transfer in a chronically catheterized pregnant sheep preparation. ${ }^{17}$ Preliminary findings indicate that the transfer of MCP across the placenta is rapid ( $<1 \mathrm{~min}$.) and that foetal concentrations exceed maternal at 90 minutes after administration.

Controversy ${ }^{18}$ surrounds the neurobehavioural tests. We accept that this examination may not be sensitive to the subtle effects of drugs. However, as Tronick $^{18}$ points out, it systematizes observations and provides the framework for close examination over the 24-hour period during which we decided to study these infants. We have chosen to use the Neurological and Adaptive Capacity Score (NACS) of Amiel-Tison, Barrier and Shnider ${ }^{13}$ because it avoids noxious stimuli and can be performed quickly. Depressed or abnormal babies would have been readily noted. Our results show that there are no apparent differences between the treated and untreated groups.

From Table $\mathbf{l}$ it can be concluded that the gastric volumes in the untreated group are highly variable and that treatment results in a significant increase in gastric emptying ( $p<0.05$ ). Furthermore, this study confirms the findings of Roberts and Shirley ${ }^{4}$ that there is a large range in gastric volumes in patients tested for 8-12 hours prior to delivery by Caesarian section. Both studies demonstrate that there is no safe time interval between the last meal and delivery which guarantees an empty stomach.

In conclusion, we have documented for the first time that metoclopramide crosses the placenta after therapeutic preoperative IV doses to parturient women undergoing elective Caesarian section. Furthermore, we have not observed any adverse effects on the neonate while we have been able to confirm differences in maternal gastric volumes between treated and untreated patients.

\section{Acknowledgements}

This work was supported by the Medical Research Council of Canada and the British Columbia Medical Services Foundation. The authors wish to thank Ms. Tracy Lakevold for her capable assistance in the preparation of this manuscript, Todd Rogers, Ph.D. (U.B.C.) for his valuable assistance in the statistical analysis of the data and L.C. Jenkins, M.D. for his assistance and encouragement during the course of this study.

\section{References}

1 Shnider, SM, Levinson G. Anesthesia for Obstetrics, Baltimore, Md., Williams \& Wilkins (1979).

2 Mendelson, $C L$. The aspiration of stomach contents into the lungs during obstetrical anesthesia. Am J Obstet Gynecol 1946; 52: 191.

3 Foulkes $E$, Jenkins $L C$. A comparative evaluation of cimetidine and sodium citrate to decrease gas- 
tric acidity: Effectiveness at the time of induction of anesthesia. Can Anesth Soc J 1981; 28: 29.

4 Roberts, $R B$, Shirley $M A$. Reducing the risk of acid aspiration during Caesarian section. Anesth Analg 1974; 53: 859.

5 Howe JP, McGowan WAW, Moore J, McCaughey $W$. Dundee $J W$. The placental transport of cimetidine. Anaesthesia 1981; 36: 371.

6 McGarry, JM A double-blind comparison of the anti-emetic effect during labour of metoclopramide and perphenazine. Br J Anaesth 1971; 43: 613.

7 Howard, FA, Sharp DS. Effect of metoclopramide on gastric emptying during labour. Br Med J 1973; 1: 446 .

8 Brock-Utne JG, Dow TG, Welman S, Dimopoulous $G E$, Moshal GE. The effects of metoclopramide on the lower esophageal sphincter in late pregnancy. Anaesth Intensive Care 1978; 6: 26.

9 Schulze-Delrieu $K$. Metoclopramide. N Engl J Med 1981; 305: 28.

10 Pinder RM, Brogden RM, Sawyer PR, Speight $T M$, Avery GS. Metoclopramide: A review of its pharmacological properties and clinical use. Drugs 1976; 12: 81.

11 Low LCK, Goel KM. Metoclopramide poisoning in children. Arch Dis Child 1980; 55: 310.

12 Riggs KW, Axelson JE, Rurak DW et al. Electroncapture determination of metoclopramide in biological fluids using fused silica capillary columns: Application to placental transport studies in sheep and humans, in press J Chromatog, 1983.

13 Amiel-Tison C. Barrier G. Shnider SM, Levinson G. Hughes SC, Stefani SJ. A new neurologic and adaptive capacity scoring system for evaluating ob stetric medication in full-term newborns. Anesthesiology $1982 ; 56: 340$

14 Nie NH, Hull CH, Jenkins JG, Steinbrenner $K$, Bent $D H$. Students' t-test subroutine of the Sta tistical Package for the Social Sciences, Version 9 (SPSS:9). McGraw-Hill, Toronto (1982).

15 Smith MA, Salter FJ. New drug evaluations: Metoclopramide. Drug Intel Clin Pharm 1980; 14: 169.

16 Woddell WJ, Marlowe $C$. Transfer of drugs across the placenta. Pharmac Ther 1981; 14:375.

17 Chapman RLK, Dawes GS, Rurak DW, Wilds PL. Breathing movements in fetal lambs and the effect of hypercapnia. J Physiol 1980; 302: 19.

18 Tronick $E$. Editorial. A critique of neonatal neurologic and adaptive capacity score (NACS). Anesthesiology 1982; 56: 338 .

\section{Résumé}

Vingt-trois patientes subissant une césarierne sous anesthésie générale pour grossesse non compliquée on été soumises à une étude à double insu. Huit patientes ont reçu du métoclopramide intraveineux, douze ont rȩ̧u du salin 0.9 pour cent, trois n'ont pu être suivies en post-opératoire. Les volumes gastriques maternels ont été mesurés et le métoclopramide maternel et foetal a été dosé par chromatographie gaz-liquide. Le score au test d'Amiel, Barrier et Schtider (neurological and adaptive capacity score 'NCAS' l a été ucilisé pour l'évaluation de la réponse du nouveau-né au métoclopramide. Les volumes gastriques maternels étaient significativement plus petits $(p<0.05)$ dans le groupe traité. $/ 1 n^{\prime} y$ a pas eu de différence marquée des scores d'Apgar, des paramètres cardiovasculaires ou des scores neurobehavioraux entre les nowveaux-nés des deux groupes. En aucun temps le taux plasmatique du métoclopranide foetal a excédé celui de sa mère. 